\title{
М.Г. Курган
}

\section{ДАНТОВСКАЯ КОНЦЕПЦИЯ АДА В ТВОРЧЕСКОЙ ПЕРЦЕПЦИИ Ф.М. ДОСТОЕВСКОГО}

В статье ставится проблема, связанная с восприятием кониепциии ада, выраженной в «Божественной Комедии» Данте, в творческом сознании Ф.М. Достоевского. Исследуются упоминания Достоевского о Данте и его произведениях и их значение для художественного мира русского писателя. Указывается на особое значение категории ада в творчестве Достоевского и значимость сопоставления в этом аспекте с поэмой Данте. Отмечаются основополагающие принцииь организации ада в «Божественной Комедии». Выявляется феномен «ношения ада в душе», актуальный для произведений Достоевского, анализируется воплощение концепции ада в повести «Двойник».

Ключевые слова: Ф.М. Достоевский, Данте, конщепџия ада, «ночение ада в душе», двойничество.

Данте Алигьери и его «Божественную Комедию» можно причислить к произведениям, составляющим мировую литературу в том смысле, который подразумевал Гете, впервые вводя это понятие. «Божественная Комедия» была написана в период с 1307 по 1321 г. и представляет собой один из самых значительных памятников литературы Средневековья, методично вобравший в себя научные, политические, философские и богословские реалии своего времени. Справедливо сам Данте оценил свой труд в тексте поэмы, причисляя себя к «славнейшей из школ», «чьи песнопенья вознеслись над светом» [1. С. 24], становясь в один ряд с Гомером, Горацием, Овидием, Лукианом и Вергилием.

В русскую культуру поэма входит с первыми переводами, которые были сделаны еще до начала XIX в. М.П. Алексеев показал в своем труде, как шло знакомство с итальянским поэтом в России, и указал на факторы, которые способствовали органичности восприятия Данте. Среди них ученый называет распространенность в русской «низовой» литературе до конца XVIII в. апокрифических «хождений по мукам» и «разговоров в царстве мертвых» (среди них, например, «Хождения Богородицы по мукам») [2. С. 197]. Другим немаловажным фактором стало повсеместное увлечение итальянской культурой в 1810-1820-х гг., усиленное культом Ита- 
лии в среде французских романтиков, воплощавших в своих произведениях итальянские реалии.

Не приходится сомневаться, что «Божественная Комедия» была прочитана Достоевским и он в полной мере осознавал ее значение. Однако свидетельства об этом произведении Данте, в сравнении с отзывами о других памятниках мировой литературы, мы находим в текстах Достоевского нечасто. В статистическом словаре языка Достоевского фиксируются четыре обращения автора к имени Данте, три из их - в художественных произведениях, однажды Достоевский упоминает Данте в критическом сочинении [3. С. 78]. Существует обращение Достоевского непосредственно к «Божественной комедии», которое мы находим в редакционном предисловии к напечатанному в журнале «Время» переводу «Собора Парижской Богоматери» В. Гюго в 1862 г. В этом предисловии Достоевский утверждает, что основной мыслью всего искусства XIX столетия явилась идея «восстановления погибшего человека, задавленного несправедливо гнетом обстоятельств, застоя веков и общественных предрассудков», которая наиболее полно выразилась в творчестве Гюго. Достоевский высказал уверенность в том, что в недалеком будущем эта идея получит свое воплощение в произведении, сопоставимом по масштабу с «Божественной Комедией» Данте [4. С. 28]. Очевидно, Достоевский считал поэму Данте своего рода образцом произведения, в котором автору во всей полноте удалось отразить суть своей эпохи и в то же время причислить свое сочинение к ряду мировых литературных памятников. Важно помнить, что данное предисловие считается одним из основополагающих эстетических манифестов Достоевского, в котором он отметил в творчестве Гюго то, к чему стремился в собственных произведениях.

Интересны в связи с приведенными выше словами Достоевского свидетельства о разработке замысла большого романа «Житие великого грешника», зафиксированные в письмах и воспоминаниях. Как известно, роман должен был иметь трехчастную структуру (что само по себе может отослать нас к поэме Данте), но главное, именно этот роман мыслился как произведение, конгениальное по своему масштабу, охвату, проблематике времени и личностям, в нем живущим. Г.М. Фридлендер в комментариях к роману «Братья Карамазовы» отмечает, что подобная идея «собора» различных русских мыслителей разного времени в одном художественном тексте оригинальна даже в рамках творчества Достоевского, и склонен более сопоставлять эту 
идею с «Божественной Комедией» Данте, чем с традицией реалистического романа XIX в. [5. С. 399-400], что вполне закономерно, если иметь в виду слова самого Достоевского о необходимости создания подобного произведения в XIX столетии.

В «Летописи жизни и творчества Ф.М. Достоевского» [6] обнаруживаются всего три упоминания о Данте, и примечательно, что каждое будет связано исключительно с произведением Достоевского «Записки из мертвого дома». Это отзывы И.С. Тургенева, А.П. Милюкова, и А.И. Герцена.

Думается, что сравнение с Данте в данном случает вполне закономерно и даже симптоматично, первая часть поэмы Данте «Ад» неизменно производила глубочайшее впечатление на читателей, а «Записки из мертвого дома», со своей стороны, уже заглавием соотносятся со смертью, загробным, потусторонним миром, адом. В «Записках...» мы находим прямые отсылки к «Божественной Комедии»: восьмиглазый плац-майор, с рысьим взглядом, который также зовется Цербером, он, словно многоголовый страж Аида, преграждающий душам выход из царства мертвых. Эта же фигура сравнивается с пауком в центре паутины, от которого расходятся свитые им кольца, сходные с кругами ада. Все эти знаки Достоевский расставляет для того, чтобы его читатель смог в действительности оценить происходящее на каторге. Воздействуя на культурные ассоциации, Достоевский достигает ужасающего эффекта, сложного по своей природе, так как его произведение отсылает сознание читателя к ужасам ада, которые воплотил Данте, а потом снова возвращает к тексту «Записок...». Так произведение Достоевского приобретает новую глубину и в то же время отчетливость и понятность читателю, потому что воспринимающее сознание идет не напрямую от символа или знака к его первичному культурному воплощению, но проходит через дантовский текст.

Сопоставление Данте и Достоевского можно проводить по разным основаниям. Однако наиболее значительным, очевидным и уместным в рамках нашего исследования представляется аспект изображения ада в произведениях данных писателей. Думается, что первым произведением Достоевского, вызвавшим прямую ассоциацию с дантовским адом, стали «Записки из мертвого дома». Другие произведения писателя также можно рассматривать в указанной парадигме, и такой взгляд представляется весьма продуктивным и адекватным художественному пространству произведений Достоевского. 
Данте в «Божественной Комедии» совершил нечто невероятное воссоздал картину преисподней, четко обозначив ее внутреннее устройство, насколько это было возможно с точки зрения человеческого ума. Поэма Данте демонстрирует удивительную продуманность с точки зрения композиции и стихотворного строя. Идея тройственности пронизывает все мироздание, которое под пером Данте обрело гармоничное художественное выражение. Ю.М. Лотман и Б.А. Успенский в статье «Роль дуальных моделей в динамике русской культуры» отмечают, что отличительной чертой именно русской культуры явилась ее четкая поляризация еще со времен средневековья, что коренным образом отличает ее от модели западной, где мир изначально разделен на три составные части [7. С. 219-254]. В этой связи проблема двойничества в произведениях Достоевского может приобретать иной масштаб, связанный с национальной обусловленностью данного феномена, который закрепился в качестве культурной модели.

Дантовский ад имеет очень строгую организацию. Он разделен на девять кругов, каждый из них уже предшествующего и каждому кругу соответствует особая страсть. На адских кругах мы встречаем не один раз особую казнь, заключающуюся в раздвоении одного человеческого существа: «...единой стала голова, И смесь двух лиц явилась перед нами, Где прежние мерещились едва. Четыре отрасли - двумя руками, А бедра, ноги, и живот, и грудь Невиданными сделались частями. Все бывшее в одну смесилось муть; И жуткий образ медленной походкой, Ничто и двое, продолжал свой путь» [1. С. 113]; «...тело безголовое шагало В толпе, кружащей неисчетный раз, И срезанную голову держало За космы, как фонарь, и голова Взирала к нам и скорбно восклицала. Он сам себе светил, и было два В одном, единый в образе двойного...» [1. С. 127].

Важнейшей особенностью адских мук, которые изображает Данте, является то, что они всегда, на всех кругах, заключены в самом человеке. Это проявлено в абсолютной богооставленности: грешники предельно одиноки. Земной мир освобождается со смертью грешника от его злодеяний и больше не участвует в них. Грех, который в земной жизни еще можно искупить покаянием, в аду доводится до абсолюта и реализуется в вечности. Вергилий так объяснил эту мысль в поэме: «Здесь каждый дух затерян Внутри огня, которым он горит» [1. С. 117]. Это поддерживает идею губительной двойственности человека. 
Другой аспект, который представляется значимым для осмысления дантовского ада, - это противопоставление живого и мертвого. Поскольку ад - это царство исключительно мертвых, то сама эта оппозиция могла родиться только при появлении живого человека в пространстве ада, что и происходит в поэме. И чуждость этого пространства повествователю ощущается постоянно, каждый подземный страж, стоящий у входа в следующий круг, вопрошает поэта о том, как и для чего он оказался в преисподней. Данная оппозиция обостряется, когда повествователь вступает в диалог с умершими и в поэму включаются истории их земной жизни. В этом видится некое последнее стремление страдающих грешников оправдать или утвердить себя. Поэт, в свою очередь, обещает увековечить их имена для живущих, устанавливая связь между миром живых и миром мертвых.

Для того чтобы понять, что составляет ад в произведениях Достоевского, обратимся к Словарю языка писателя, в котором слово «ад» представлено в трех значениях: 1. Нравственные страдания, муки, испытываемые кем-либо; хаос и ужас, царящие в душе. 2. Тяжелые условия, невыносимая обстановка, пребывание в которой мучительно. 3. Преисподняя, место, где души грешников после смерти подвергнутся вечным мукам [8. С. 5-8]. В этих трех значениях есть последовательная метафоризация и отдаление от основного значения - преисподней, которое реже всего встречается в произведениях Достоевского. Во втором значении еще наблюдаем сохранение привязанности ада к определенному топосу, и отметим, что в этом значении часто выступал Петербург в художественных произведениях и письмах. Другой яркий образ, иллюстрирующий данное значение, - сцена в бане в произведении «Записки из мертвого дома», которая напомнила И.С. Тургеневу картины дантовского ада. Первое же, самое частотное, значение ада в творчестве Достоевского уже не привязано к конкретному местоположению, более того, оно переносится исключительно в сознание и душу человека. Отчетлив для творчества Достоевского мотив «ношения ада в душе», который проявляет себя уже в ранних произведениях писателя и сохраняется до последнего его романа. Все герои первостепенного значения так или иначе переживают внутренне адское горение, связанное с глубочайшим душевным потрясением, доходящим часто до болезненного состояния.

Ад, лишенный топоса и заключенный в сознание, трудно описать детализированно и подробно, с одной стороны, он становится индивидуализированным, «личным» адом, а с другой - сохраняет свои 
общие свойства, главное из которых - муки. И они действительно схожи с муками грешников в аду, который изображает Данте: они соответствуют страстям человека, который их переживает, и определяются его сознанием. Но для героев Достоевского в адских муках внутреннего переживания всегда кроется надежда на спасение и выход из ада: ведь они еще не в явном царстве мертвых, они еще на земле могут почувствовать дыхание адского пламени, выжигающего душу, и отречься от него.

Обыкновенно ад мыслится как некое место, топос, куда попадают после смерти грешники и где они обречены вечно принимать муки. Представления об устройстве ада могут разниться, однако сохраняется главное: ад в человеческом видении - это всегда некое место, имеющее какие-либо признаки привычного земного пространства, иначе человеческое мышление было бы неспособно воплотить образ ада в сознании. Так, в поэме Данте ад имеет хотя и весьма сложную, но представимую организацию, которая явилась источником вдохновения для художников, запечатлевших ад на живописных полотнах. В связи с этим вспоминаются слова Свидригайлова из романа «Преступление и наказание», которыми он характеризует вечность: «Нам вот всё представляется вечность как идея, которую понять нельзя, что-то огромное, огромное! Да почему же непременно огромное? И вдруг, вместо всего этого, представьте себе, будет там одна комнатка, эдак вроде деревенской бани, закоптелая, а по всем углам пауки, и вот и вся вечность» [9. С. 221]. В данном случае Свидригайлов говорит о вечности для грешников, в сущности - об аде.

Но определяется ли существование ада как феномена пространственным бытованием? Если понимать пространство как форму существования материи, характеризующуюся протяженностью и неким объемом, то феномен «ношения ада в душе», являющийся, как было сказано выше, для Достоевского одним из определяющих, с трудом вписывается в это понятие. Таким образом, пространство как некий локус не является для феномена ада существенно важным, это и позволяет аду в изображении Достоевского не быть закрепленным только лишь за топосом внутри материального мира, но переноситься в пространство иного рода - пространство сознания, мысли, душевного устройства. Имея в виду сказанное, мы можем отметить еще один важный аспект феномена ада - это непременное наличие сознания, воспринимающего мучения. Об этом стоит упомянуть особо, поскольку ад у Достоевского, еще сохраняющий пространственную 
прикрепленность, имеет несомненные признаки топоса потустороннего, дьявольского, и прямо номинируется как «ад», но неизменно в указанном пространстве помещается человек, который испытывает на себе его инфернальное воздействие, борется с ним самим и его порождениями. В том случае, когда ад перемещается в сознание, субъект этого сознания и определяет, какой именно вид примут его адские муки, тогда есть смысл говорить об аде «индивидуальном».

Ад в изображении Данте - это напрямую преисподняя, потустороннее пространство, куда герой попадает с помощью проводника, принадлежащего этому пространству. У Достоевского феномен ада сохраняет свои потусторонние характеристики, которые особым образом маркированы в тексте. Можно предположить, что не пространство организует ад определенным образом, но ад влияет на пространство, искажая его. Под влиянием сил, постичь которые человек неспособен, пространство перестает быть исключительно рациональным, осмысляемым, переходит в разряд фантастического. Именно этот процесс часто наблюдается в художественных текстах Достоевского в изображении Петербурга.

Остановимся подробнее на значении ада, выделяемом в Словаре языка писателя как второе по частотности употребления, определяющееся как «тяжелые условия, невыносимая обстановка, пребывание в которой мучительно» [8. С. 5]. Для этого необходимо определить, какое пространство Достоевский обозначал как «ад». В первую очередь в данном контексте, несомненно, стоит говорить о Петербурге. Писатель не раз называл Петербург «сущим адом» в своих письмах, но и в художественных произведениях город Петра нередко представляет собой место определенно инфернальное, не подчиненное рациональным законам, по которым пытались его выстроить. Весьма репрезентативна в этом отношении повесть Достоевского «Двойник», в которой Петербург по праву можно назвать одним из действующих лиц, приводящих сюжет повести в движение.

Ф.М. Достоевскому свойственно очень точно определять место действия своих произведений. Во всех романах «пятикнижия» хронотоп будет четко отмечен, это дает основания полагать, что таким образом Достоевский указывает на значимость места событий. Повесть «Двойник», в частности, может служить ярким репрезентантом топографической точности автора. Многие исследователи обращали внимание на особую выстроенность и значимость маршрута, по которому движется герой повести господин Голядкин. В самом начале повест- 
вования мы узнаем точный адрес проживания героя и, по выходу его из дома, можем легко прослеживать его точный маршрут, поскольку повествователь неустанно указывает названия улиц и переулков. Однако наибольший интерес в этом контексте, вызывает путь Голядкина от дома Берендеевых до своей квартиры. Титулярный советник Голядкин, изгнанный с бала в честь дня рождения Клары Олсуфьевны, вне себя выбежал на набережную Фонтанки, возле самого Измайловского моста, спасаясь от врагов, от преследований. Он пробежал набережную, перешел Аничков мост, миновал часть Невского, поворотил в Литейную, свернул в Итальянскую, и, наконец, оказался дома, в Шестилавочной. Несомненно, в выборе пути нужно видеть особый авторский умысел.

Необозначенным остается название улицы, на которую повернул Голядкин, следуя из Литейного, поскольку тогда существовало две Итальянских: Большая и Малая. Но наш герой поворачивает направо, а значит, в М. Итальянскую, а на углу Литейного и М. Итальянской и поныне расположена Мариинская городская больница (тогда Петербургская больница для бедных). Удивительно, что больница в Москве, где служил отец Достоевского, построена одновременно и по одному с ней проекту. В казенной квартире ее левого флигеля, подобного петербургскому, прошли детство и отрочество автора «Двойника».

Но проследим далее путь героя. Он движется вдоль Фонтанки уникальной реки Петербурга, на которой расположено семь однотипных мостов, герой же пробегал мимо четырех из них, причем каждый был назван своим именем, что не может быть осознано как простая случайность. К тому же повествователь точно отмечает время действия - ровно полночь, что также свидетельствует о наступлении особо значимого момента в повествовании. Именно в этот момент герой выбегает на набережную Фонтанки. Первый мост (к нему выбежал наш герой, изгнанный из дома Берендеева) Измайловский. «Ветер выл в опустелых улицах, вздымая выше колец черную воду Фонтанки и задорно потрогивая тощие фонари набережной, которые в свою очередь вторили его завываниям тоненьким, пронзительным скрипом, что составляло бесконечный, пискливый, дребезжащий концерт, весьма знакомый каждому петербургскому жителю» [10. С. 138] - от этой зарисовки, иллюстрирующей на первый взгляд совершенно обыденную картину, определенно веет нездешним холодком: ночью город начинает жить особой жизнью. На своем пути герой проходит три 
идентичных моста, которые своеобразно отсчитывают столкновения Голядкина с двойником. Но прежде герой преодолевает Аничков мост, украшенный скульптурами работы Петра Карловича Клодта, в качестве которых выступили античные близнецы Диоскуры, укротители коней.

Можно говорить о том, что этим точным маршрутом героя Достоевский обозначает особое, уникальное пространство Петербурга, указывает на то, что в никаком другом городе и даже в другой улице не могло произойти больше такой встречи. Набережная Фонтанки становится одной из точек, где совершается кризис героя, радикальная смена и неожиданный перелом в его судьбе. В этом контексте можно говорить о границе на нескольких уровнях. Это внутреннее состояние пограничности, которое переживает господин Голядкин: он находится на грани сумасшествия, на грани неразличения реальности и ирреальности. Другая граница - это разделение собственной личности героя и его двойника Голядкина-младшего. Эта граница тоже становится зыбкой даже для самого героя. И еще одна граница, уже исключительно внешняя, связана с собственно пограничной семантикой набережной. Тяжелая гранитная набережная Фонтанки отделяет «черную воду» от пространства обитания и маршрута героя - земли. Не раз на своем пути в таинственную ночь встречи с двойником герой останавливается и вглядывается в толщу воды под ним. В этот момент, как отмечает повествователь, даже измерение времени производится с трудом: «господин Голядкин остановился, оперся на перила набережной в положении человека, у которого вдруг, совсем неожиданно, потекла носом кровь, и пристально стал смотреть на мутную, черную воду Фонтанки. Неизвестно, сколько именно времени проведено было им в этом занятии» [10. С. 139]. Пространство набережной Фонтанки, а шире - пространство Петербурга, оформляет и определяет общее состояние пограничности в повести, что связано также и с исторической границей города, которая раньше проходила именно по Фонтанке, ставшей затем равноправным центром города. В данном случае ассоциация с темными тяжелыми водами другой известной реки, также являющей собой своеобразную границу, довольно прозрачна: речь идет о реке Стикс, по которой Харон в своей ладье переправлял души грешников. Именно по этой реке проплывает со своим провожатым герой «Божественной комедии» Данте. Семантика пограничности, принадлежащая реке в данном контексте, расширяется, и все менее 
ясно, какой реальности принадлежит пространство, по которому движется господин Голядкин: обыденной или потусторонней.

Изображая пространство Петербурга в повести, Достоевский намеренно расставляет акценты, четко номинируя улицы, мосты, реки, проводя Голядкина именно по тем петербургским местам, которые имеют отношение к феномену двойничества и составляют его концептосферу. Путь Голядкина есть путь фантастический, выпадающий из нормального течения жизни, и пространство Петербурга в повести действительным образом искажается, герой в этом искаженном мире уже не может руководить собой полноценно, он управляем Петербургом, который ведет его, приближая неизбежную встречу с двойником. Именно поэтому пространство Петербурга приобретает инфернальные черты, двойник предстает словно его естественное порождение. Действительно, ловкий, вертлявый, говорливый чиновник, который знает, как угодить вышестоящим по чину, является воплощением особого петербургского типа, явившегося в почти абсурдной крайности. Становится явной и связь концепта Петербурга с феноменом ада, подземного царства, что выражается в повести «Двойник» в первую очередь в образе двойника - Голядкина-младшего.

Данный образ типологически восходит к древним верованиям, согласно которым двойник является вестником скорой смерти. Нет сомнений в том, что Достоевский, как образованный человек, не мог не знать систему народных примет, связанных со смертью, о чем говорят и другие его произведения, в которых обнаруживаются такие приметы. Так включается мифологическое значение двойника, которое будет очень важно в связи с феноменом ада, поскольку буквальным образом двойник в повести становится проводником Голядкинастаршего в царство смерти, одновременно предвещая ее. Именно после появления двойника в и без того незавидной судьбе господина Голядкина все стало стремительно рушиться: его с позором выгнали из дома, где герой искал женитьбы, его сместили со службы, составлявшей все содержание жизни, к финалу повести герой находится на грани сумасшествия. И причиной всех несчастий становится двойник господина Голядкина, он буквальным образом конструирует ад вокруг героя, влияя на пространство и окружающих его людей.

О том, что двойник - вестник нездешнего мира, говорит множество красноречивых деталей, которыми обставлено первое появление двойника: он появляется в непогодную, мистически вьюжную ночь, когда часы пробили полночь, извещая о наступлении особого време- 
ни. В этот момент сам господин Голядкин показан пересекающим реку по мосту, будто поставлен у предельной черты бытия. Незнакомец, который окажется двойником героя, возникает на перекрестке. Писатель дважды указывает на перекресток дорог или перекресток улиц: Невского и Литейного, Литейного и Итальянской. Известно, что перекресток - место весьма значимое в большинстве древних культур, в котором вероятнее всего встреча с потусторонними силами. Таким образом, соотнесенность образа двойника с чертом выявляется в повести повсеместно. Достоевский в черновых записях к «Двойнику» указывает на то, что «младший все знает про старшего и все узнает» [10. С. 434], приписывает двойнику «сверхъестественное могущество», что прямым образом указывает на нематериальную, потустороннюю природу двойника.

Так герой повести господин Голядкин постепенно теряет возможность каким-либо образом управлять своей судьбой и влиять на ход событий. Он оказывается совершенно бессилен перед неотвратимой и ужасающей реальностью, которая убивает его человеческое достоинство и всякую амбицию. Абсурдная реальность венчается фантастическим образом двойника, который вмешивается в обыденный ход вещей так, что этот ход не только не нарушается, а напротив, поддерживается. Двойник словно угадывает внутренние основания движения и жизни человеческого общества и действует соразмерно им, ни разу не совершив оплошности, чего нельзя сказать о настоящем господине Голядкине. А Петербург становится своего рода фантастической декорацией этого действа, искажаясь под влиянием потусторонних сил, он приводит героя к фатальной встрече.

Такое изображение Петербурга не случайно в творчестве Достоевского и связано в том числе и с его личным восприятием города. В 1840-е гг., когда создавались его первые литературные произведения, писатель планировал путешествие по Европе, о чем Достоевский сообщал брату Михаилу в письме от 7 октября 1846 г. Именно тогда Петербург обозначается как «сущий ад» и противопоставляется желанному посещению Европы, в первую очередь - Италии [11. С. 127]. Однако позже внутри данного противопоставления указанные полюса полностью поменяют свое значение.

Спустя много лет Достоевскому вместе с женой суждено будет провести в когда-то столь желанной Италии, во Флоренции, несколько мучительных месяцев. У Достоевских не было денег на отъезд, и они были вынуждены жить в условиях страшной жары, тесноты 
съемной квартиры и отсутствия средств. Именно в этот период в письмах формируется значимая параллель, связавшая обитание во Флоренции с образом ада (что прежде было прерогативой Петербурга), для обозначения данной параллели важны определенные маркёры, описывающие прежде всего переживание тоски, скуки и невыносимой жары, когда каждое строение накаляется словно камень в печи. Образ ада в данном случае актуализируется одновременно с разных аспектов: Достоевский сравнивал пребывание во Флоренции с сибирской каторгой, к чему отсылает также неоднократно описанная флорентийская жара в сопоставлении с известной сценой в бане в произведении «Записки из мертвого дома». И наконец, третьей деталью становится piccola bestia - тарантул, сюжет о котором позже станет основой одной из статей «Дневника писателя» [12. С. 106-111] и в данном контексте связывается частотным использованием сравнений героев уже упомянутого произведения с пауками, которые являются непременными обитателями ада, по Достоевскому. Как отмечает М.П. Гребнева в монографии «Персональные флорентийские мифы в русской словесности XIX-XX вв.»: «Ад в “Записках” нельзя себе представить не только без бани, жары, тесноты, но и пауков» [13. C. 11]. Кроме того, данный сюжет коррелирует с приведенным выше высказыванием Свидригайлова, предполагающим, что именно пауки будут наполнять вечность грешника.

Другим важным аспектом, который составляет внутреннее устройство ада, по Достоевскому, является динамика перемещений героя в пространстве. Движение сюжета повести неразрывно связано и часто провоцируется буквальным перемещением господина Голядкина из одного места Петербурга в другое. И для маркирования этих мест служит, в частности, точная номинация улиц, домов и других архитектурных объектов. Уже в начале повествования обозначается место проживания Голядкина - Шестилавочная улица, затем в голубом экипаже герой отправляется на Невский проспект, а оттуда - к доктору Крестьяну Ивановичу, в «пятиэтажный дом на Литейной». При этом каждая смена географического положения сопровождается сменой настроения героя: дома Голядкин находится в приятном волнении, ожидании, он даже весел. На Невском, случайно повстречав своего начальника, но так и не поприветствовав его, герой впадает в страшное смущение. У доктора же Голядкиным овладевает раздражение, нервное беспокойство: «Тогда, впрочем необыкновенно странным образом, разрешилось и второе движение господина Голядкина. Губы 
его затряслись, подбородок запрыгал, и герой наш заплакал совсем неожиданно» [10. С. 118]. После посещения доктора Голядкин снова отправляется на Невский проспект, где совершает множество дел, для него крайне необычных: он торгуется с несколькими купцами в Гостином дворе о покупке различных безделушек на знатную сумму, отправляется в мебельный магазин, где «сторговал мебели на шесть комнат», долго приценивается к дамским нарядам, затем «приказал своему кучеру остановиться возле одного известного ресторана на Невском проспекте, о котором доселе он знал лишь понаслышке» [10. С. 123], одним словом суетится и перемещается беспрестанно. Но, как мы узнаем позднее, конечной целью его пути был дом Олсуфия Ивановича Берендеева, где был званый обед в честь дня рождения его дочери. Однако господину Голядкину отказано, когда он пытается попасть в дом, лакей сообщает, что его не велено принимать, и Голядкин в страшном потрясении и смущении отправляется обедать в трактир. Но уже в следующей главе мы находим героя «в сенях, на черной лестнице квартиры Олсуфия Ивановича», Голядкин все же врывается на бал непрошеным гостем, откуда с позором его изгоняют.

Именно после этого происшествия, оказавшись «ужасной» петербургской ночью один на один с городом, герой повстречает своего двойника. И в течение всего дальнейшего повествования господин Голядкин постоянно пребывает в движении: из дома в департамент, из департамента в трактир, кофейню, и снова домой. Поминутно герой находится в погоне за Голядкиным-младшим, который и задает динамичный темп движения, постоянно скрываясь и изворачиваясь. На пике отчаяния, в ночь, когда должна была решиться его судьба, господин Голядкин бредет по Петербургу и замечает вдруг, что «стоит на Литейной. Погода была ужасная: была оттепель, валил снег, шел дождь, - ну точь-в-точь как в то незабвенное время, когда, в страшный полночный час, начались все несчастия господина Голядкина. "Какой тут вояж! - думал господин Голядкин, смотря на погоду, - тут всеобщая смерть...» [10. С. 213]. Это внутреннее обреченное восклицание героя вряд ли можно адресовать только лишь к погоде: оно сообщается со всем окружающим Голядкина пространством ночного, промозглого, поистине инфернального города, в котором для героя нет надежды на спасение.

Непрестанное перемещение героя в пространстве коррелирует с первоначальным заглавием повести «Приключения господина Голядкина», которое впоследствии было изменено. Данный способ дей- 
ствия героя внутри повествования, заключающийся в постоянном движении, изменении местонахождения, своеобразном «хождении» сообщается с «путешествием» героя другого произведения, а именно «Божественной комедии» Данте, сам принцип повествования которой основывается на хождении, перемещении. Но, как и в «Двойнике», принцип путешествия становится гораздо большим, чем просто внутренним сюжетом, - он влияет на метрическую и содержательную организацию поэмы. О. Мандельштам в книге «Разговор о Данте» писал: «"Inferno" и в особенности "Purgatorio" прославляет человеческую походку, размер и ритм шагов, ступню и ее форму. Шаг, сопряженный с дыханьем и насыщенный мыслью, Дант понимает как начало просодии. Для обозначения ходьбы он употребляет множество разнообразных и прелестных оборотов» [14. С. 112]. Как и у героя «Божественной комедии», у господина Голядкина есть свой «проводник» по аду Петербурга - его собственный двойник. Именно он увлекает героя, подстрекает его, пишет любовное послание от лица Клары Олсуфьевны, окончательно погубив тем Голядкина-старшего. И если Вергилий для своего спутника - «возлюбленный» и «милый» отец, то мотив кровного родства, а именно братства, между двумя Голядкиными оборачивается непримиримой враждой вплоть до желания истребить другого вовсе.

Так при сопоставлении двух указанных произведений обнаруживается связь двойничества и ада как феноменов, воплощенных в художественном пространстве. Очевидно их диалектическое взаимовлияние, полюса которого различны у Данте и Достоевского. В «Божественной Комедии» раздвоенность поначалу выступает лишь как одна из возможных адских мук. Однако каждый встречающийся в аду Данте грешник по сути двойник самого себя, бледная искаженная тень той личности, которую подавил и загубил грех человека, ему поддавшегося. У Достоевского же имеет место обратный процесс: раздвоенность вызывает ад в душе человека и часто ведет его к гибели, что являет собой судьба господина Голядкина. Этот процесс рождает феномен «ношения ада в душе», индивидуального ада, который многократно ужаснее физических мук, поскольку является человеку уже на земле, но открыть его другому не представляется возможным, так как муки сознания настигают человека в тотальном одиночестве. В этом, думается, глубокая трагедия, как самого Достоевского, так и многих его героев. 


\section{Лuтература}

1. Божественная комедия / Данте Алигьери; пер. М. Лозинского; изд. подгот. И.Н. Голенищев-Кутузов; АН СССР. М.: Наука, 1968. 627 с.: ил. (Литературные памятники).

2. Алексеев М.П. Сравнительное литературоведение / отв. ред. Г.В. Степанов; АН СССР. Отд-ние лит. и яз. Л.: Наука, 1983. 444, [3] с.

3. Шайкевич А.Я. Статистический словарь языка Достоевского / А.Я. Шайкевич, В.М. Андрющенко, Н.А. Ребецкая; Рос. акад. наук. Ин-т рус. яз. им. В.В. Виноградова. М.: Языки славян. культуры (Кошелев), 2003. 832 с. (Studia philologica).

4. Достоевский Ф.М. Полное собрание сочинений: в 30 т. Публицистика и письма: [в 13 т.]. Т. 20 / [редкол.: В.Г. Базанов (гл. ред.) и др.; Акад. наук СССР. Ин-т рус. лит. (Пушкинский Дом)]. Ленинград: Наука. Ленинградское отделение, 1980. 431, [1] с., [1] л. портр.

5. Достоевский Ф.М. Полное собрание сочинений: в 30 т. Художественные произведения: [в 17 т.]. Т. 15 / [редкол.: В.Г. Базанов (гл. ред.) и др.; Акад. наук СССР, Ин-т русской литературы (Пушкинский Дом)]. Ленинград: Наука, Ленинградское отделение, 1976. 623, [1] с.

6. Летопись жизни и творчества Ф.М. Достоевского: в 3 т. (1821-1881). Т. 3: 1875-1881 / сост.: И.Д. Якубович и др.; под ред. Н.Ф. Будановой, Г.М. Фридлендера; РАН. Ин-т рус. лит. СПб.: Академический проект, 1995. 614 с.

7. Успенский Б.А. Избранные труды. Т. 1. М.: Гнозис, 1994. 429, [1] с.: ил. (Язык. Семиотика. Культура)

8. Словарь языка Достоевского: идиоглоссарий / [авт.-сост.: Е.Л. Гинзбург и др.]; гл. ред. Ю.Н. Караулов; Учреждение Российской акад. наук. Ин-т рус. яз. им. В.В. Виноградова РАН. М.: Азбуковник, 2008.

9. Достоевский Ф.М. Полное собрание сочинений: в 30 т. Художественные произведения: в 17 т. Т. 6 / [редкол.: В.Г. Базанов (гл. ред.) и др.; Акад. наук СССР. Ин-т рус. лит. (Пушкинский Дом)]. Л.: Наука. Ленинградское отделение, 1973. 421, [2] с., [1] л. портр.: факс.

10. Достоевский Ф.М. Полное собрание сочинений: в 30 т. Художественные произведения: в 17 т. Т. 1 / [редкол.: В.Г. Базанов (гл. ред. ) и др.; Акад. наук СССР, Ин-т рус. лит. (Пушкинский Дом). Л.: Наука. Ленинградское отделение, 1972. 517, [2] с., [1] л. портр.

11. Достоевский Ф.М. Полное собрание сочинений: в 30 т. Публицистика и письма: [в 13 т.]. Т. 28, кн. 1 / [редкол.: В.Г. Базанов (гл. ред.) и др.; Акад. наук СССР. Ин-т русской литературы (Пушкинский дом)]. Л.: Наука. Ленинградское отделение, 1985. 551, [1] с., [1] л. портр.

12. Достоевский Ф.М. Полное собрание сочинений: в 30 т. Публицистика и письма: [в 13 т.]. Т. 23 / [редкол.: В.Г. Базанов (гл. ред.) и др.; Акад. наук СССР. Ин-т русской литературы (Пушкинский Дом)]. Л.: Наука. Ленинградское отделение, 1981. 422, [2] c.

13. Гребнева М.П. Персональные флорентийские мифы в русской словесности XIX-XX вв. Томск: Изд-во Том. ун-та, 2015. 124 с.

14. Мандельштам О.Э. Слово и культура: [сборник] / [сост. и примеч. П. Нерлера; вступ. ст. М.Я. Полякова]. М.: Сов. писатель, 1987. 319, [1] с.: ил. 


\section{DANTE'S INFERNO IN F.M. DOSTOEVSKY'S CREATIVE PERCEPTION}

Imagology and Comparative Studies, 2015, 1(3), pp. 160-176. DOI: 10.17223/24099554/3/10

Kurgan Marina G. Tomsk State University (Tomsk, Russian Federation). E-mail: marina_sunrise@mail.ru

Keywords: F.M. Dostoevsky, Dante, Inferno, 'wearing hell on my heart', doppelgangers.

Dante's Divine Comedy can be attributed to the works of world literature. The first Russian translations of Dante's Divine Comedy appeared in the early 19th century, which made the poem an integral part of Russian culture. There is no doubt that Dostoevsky read The Divine Comedy and was fully aware of its significance. His editorial to the translation of Victor Hugo's Notre Dame published in the jounral Vremya in 1862 contains a direct reference to Dante's poem. Apparently, Dostoevsky considered The Divine Comedy a model work in which the author managed to capture the essence of his era and achieve that his literary was included in the list of world literature masterpieces. The Annals of Dostoevsky's Life and Creative Works contains only three references to Dante, each of which is connected with Dostoevsky's Notes from the House of the Dead. The comparison with Dante in this case seems natural and even symptomatic. The first part of Dante's poem, "Inferno", has always produced a deep impression on readers, and Notes from the House of the Dead relate to death, afterlife, other worlds, and hell even in its title. Other works by Dostoevsky can also be analysed within this paradigm. This appoach appears very productive and adequate to the artistic space of Dostoevsky's works.

Dante's Inferno has a very strict structure. It is divided into nine circles, each of which is narrower than the previous. Each circle corresponds to a particular passion. There the reader meets a particular penalty many a time. This penalty implies the appearance of someone's dual personality. The most important feature of the torments represented by Dante is that they are always, in all circles, innate to a person. Another aspect that seems important for understanding Dante's Inferno is the opposition of the living and the dead.

To understand how the Hell in Dostoevsky's works is made, it is necessary to address the writer's vocabulary, in which the word 'hell' has three menaings. These meanings reflect consistent metaphorization and distancing from the main meaning - the underworld, which is less often found in Dostoevsky's works. The motif of 'wearing hell on the heart' is also obvious in Dosteovsky's works. It is manifested in his early works to remain topical up to his last novel. Hell by Dostoevsky, though spatially fixed, is unmistakably the otherworldly diabolical topos named directly as Hell. Yet in this space there is always a person who suffers from the infernal impact and struggles against it and its creations.

Dostoevsky tends to specify the location of his works. All the novels of his 'Pentateuch' have a marked chronotope. It gives the reason to believe that this was the way for Dostoevsky to emphasise the importance of the scene. The story The Double, in particular, is a vivid representation of the writer's topographical accuracy. Golyadkin's path is visionary, falling out of the normal course of the life. The space of St. Petersburg in the novel is distorted, so the hero in this distorted world has no free will any longer; he is ruled by St. Petersburg that inevitably leads him to his doppelganger. This image of St. Petersburg is typical for Dostoevsky and can be related to his personal perception of the city. In the 1840s, the period of his first literary works, the writer planned a trip to Europe, as he wrote to his brother Mikhail in the letter of October 7, 1846. It was then when St. Petersburg is referred to as 'hell' and contrasted to the coveted visit to Europe, particularly to Italy. However, later in the opposition of these poles to completely change its meaning. Later, however, these poles will completely change their meanings within this opposition. 
The hero's unceasing movement in the space correlates with the original title of the novel - The Adventures of Mr. Goliadkin. This method of the hero's action within the narration consists in constant motion, changing locations. This kind of 'wandering' correlates with the 'journey' of the hero of Dante's Divine Comedy, the narrative of which is based on descent. Comparing the above-mentioned works reveals the connection of the phenomena of dopplegangers and hell embodied in the artistic space, with obviously dialectal interaction and different poles.

\section{References}

1. Dante Alighieri. (1968) Bozhestvennaya komediya [The Divine Comedy]. Translated from Italian by M. Lozinsky. Moscow: Nauka.

2. Alekseev, M.P. (1983) Sravnitel'noe literaturovedenie [Comparative Literature Studies]. Leningrad: Nauka, 1983.

3. Shaykevich, A.Ya. (2003) Statisticheskiy slovar' yazyka Dostoevskogo [The Statistical Language Glossary of Dostoevsky]. Moscow: Yazyki slavyanskoy kul'tury.

4. Dostoevsky, F.M. (1980) Polnoe sobranie sochineniy: v 30 t. [Complete Works. In 30 vols.]. Vol. 20. Leningrad: Nauka.

5. Dostoevsky, F.M. (1976) Polnoe sobranie sochineniy: v 30 t. [Complete Works. In 30 vols.]. Vol. 15. Leningrad: Nauka.

6. Budanova, N.F. \& Fridlender, G.M. (1995) Letopis' zhizni i tvorchestva F.M. Dostoevskogo: V 3 t. (1821-1881) [The Annals of Dostoevsky's Life and Creative Works. In 3 vols. ]. Vol. 3. St. Petersburg: Akademicheskiy proekt.

7. Uspensky, B.A. (1994) Izbrannye trudy [Selected Works]. Vol. 1. Moscow: Gnozis.

8. Karaulov, Yu.N. (ed.) (2008) Slovar' yazyka Dostoevskogo: idioglossariy [Dostoevsky's Idioglossary]. Moscow: Azbukovnik.

9. Dostoevskiy, F.M. (1973) Polnoe sobranie sochineniy: $v 30 t$. [Complete Works. In 30 vols.]. Vol. 6. Leningrad: Nauka.

10. Dostoevskiy, F.M. (1972) Polnoe sobranie sochineniy: v 30 t. [Complete Works. In 30 vols.]. Vol. 1. Leningrad: Nauka.

11. Dostoevskiy, F.M. (1985) Polnoe sobranie sochineniy: $v 30 t$. [Complete Works. In 30 vols.]. Vol. 28. Leningrad: Nauka.

12. Dostoevskiy, F.M. (1981) Polnoe sobranie sochineniy: $v 30$ t. [Complete Works. In 30 vols.]. Vol. 23. Leningrad: Nauka.

13. Grebneva, M.P. (2015) Personal'nye florentiyskie mify v russkoy slovesnosti XIX$X X v v$. [Personal Florentine Myths in Russian Literature of the 19th-20th Centuries]. Tomsk: Tomsk State University.

14. Mandelstam, O.E. (1987) Slovo i kul'tura [Word and Culture]. Moscow: Sovetskiy pisatel'. 